\title{
Infections after Auxiliary Partial Liver Transplantation. Experiences in the First Ten Patients
}

\begin{abstract}
Summary: In ten auxiliary partial liver transplant recipients selective bowel decontamination (SBD) was used to reduce infections due to gram-negative microorganisms and fungi. During SBD no gram-negative infections occurred. Candida peritonitis was observed in one patient. After discontinuation of SBD serious infections of gram-negative origin did occur and three fungal infections were seen. SBD seems to have a favourable effect in reducing infections by gram-negative microorganisms and fungi. Most striking was the number of enterococcal infections that occurred. Five out of ten patients developed enterococcal infections which in two cases contributed to a fatal outcome. These infections occurred after increase of the number of enterococci in faeces and concomitant positive cultures of bile, ascites or wound drains. This increase could be due to the use of SBD. Also, the kind of biliary anastomosis may play an important role in the relatively high incidence of enterococcal infections. In the postoperative period, recurrence of hepatitis B infection in the liver graft was observed in all patients with cirrhosis due to this virus. Problems caused by other viral infections or protozoal infections remained limited in these ten patients.
\end{abstract}

Zusammenfassung: Infektionen nach partieller auxiliärer Lebertransplantation. Erfahrungen bei den ersten zehn Patienten. Bei Patienten, bei denen eine auxiliäre, partielle Lebertransplantation durchgeführt wurde, wurde die selektive Darmdekontamination (SBD) eingesetzt, um Infektionen durch gramnegative Mikroorganismen und Pilze zu vermindern. Während SBD traten keine Infektionen durch gramnegative Bakterien auf. Bei einem Patienten wurde eine CandidaPeritonitis beobachtet. Nach Beendigung der SBD kam es zu schweren Infektionen durch gramnegative Bakterien, außerdem zu drei Pilzinfektionen. SBD hat offensichtlich einen günstigen Einfluß im Hinblick auf eine Verminderung von Infektionen durch gramnegative $\mathrm{Er}$ reger und Pilze. Bemerkenswert hoch war die Zahl der aufgetretenen Enterokokkeninfektionen. Bei fünf der zehn Patienten traten Enterokokkeninfektionen auf, die in zwei Fällen den letalen Ausgang mitbestimmten. Diesen Infektionen gingen ein Anstieg der Enterokokkenzahlen im Stuhl und zugleich positive Kulturen in Galle, Aszites und Wunddrainagen voraus. Es ist möglich, daß die SBD die Zunahme von Enterokokkeninfektionen begünstigte. Auch die Art der Gallengangsanastomose kann hierzu wesentlich beigetragen haben. Bei allen Patienten, bei denen die Zirrhose durch $\mathrm{He}$ patitis B Virus verursacht war, kam es postoperativ zu einem Rezidiv durch dieses Virus im Lebertransplantat. Probleme durch andere virale oder Protozoeninfektionen hielten sich bei diesen zehn Patienten in Grenzen.

\section{Introduction}

Liver transplantation has long remained in the experimental phase but is now an accepted therapy for almost all forms of acute and chronic liver failure [1-6]. Infectious complications remain a major factor in morbidity and mortality among liver transplant recipients. The incidence of infectious complications after liver transplantations has been reported to be 66 to $88 \%$ [7-9]. Gram-negative microorganisms, fungi and cytomegalovirus (CMV) were the most important causative agents. Particularly gram-negative and fungal infections resulted in a high mortality (53 to 69\%) $[10,11]$. It has been stated that selective bowel decontamination (SBD) could result in a lower incidence of gramnegative and fungal infections $[1,12]$.

In October 1986 an auxiliary partial liver transplantation program was started in our hospital. We did not expect the number of patients to be sufficient for a prospective randomised trial on the effects of SBD. All patients therefore received $S B D$. We report our experiences in the first ten patients.
The relatively high risk of hepatitis $B$ reinfection in HBsAg-positive liver transplant patients has often been mentioned $[13,14]$. The recurrence of hepatitis $B$ virus infection of the graft, with or without coinfection with hepatitis delta virus, was therefore followed as well.

\section{Patients and Methods}

Study population, antimicrobial therapy, laboratory methods and graft function: Between October 1986 and April 1988, 11 auxiliary partial liver transplantations were performed in ten patients.

Received: 14 November 1989/Revision accepted: 7 March 1990

J. H. van Zeijl, M. D., J.F.Stuiters, Ph. D., Prof. Dr. M.F. Michel, Department of Clinical Microbiology; H.J. Metselaar, M. D., P.J. A. Willemse, M. D., Prof. Dr. S. W. Schalm, Department of Internal Medicine II; Prof. Dr. H. A. Bruining, Prof. Dr. O.T. Terpstra, Department of Surgery, University Hospital, Dr. Molewaterplein 40, NL-3015 GD Rotterdam; $A$. C. M. Kroes, M. D., Ph. D., Department of Virology, Erasmus University Rotterdam and University Hospital, P. O. Box 1738, NL-3000 DR Rotterdam, The Netherlands. 
Table 1: Patient characteristics and data on duration and effect of SBD.

\begin{tabular}{|c|c|c|c|c|c|c|c|c|c|c|}
\hline 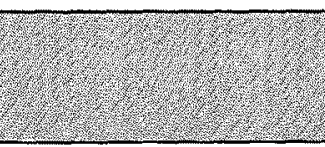 & 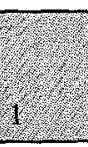 & & $\begin{array}{l}3 \\
3 \\
3 \\
3\end{array}$ & 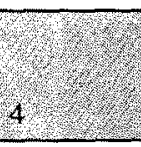 & 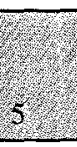 & ment no. & (3) & 8. & 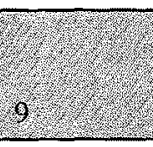 & 10 \\
\hline Sex & M & $\mathbf{M}$ & M & $M$ & $\mathrm{~F}$ & $\mathrm{~F}$ & $\mathrm{~F}$ & M & M & M \\
\hline Age* & 36 & 31 & 40 & 26 & 49 & 53 & 18 & 50 & 32 & 41 \\
\hline Etiology of liver failure** & HBV & $?$ & $\mathrm{HBV} / \mathrm{HDV}$ & $\mathrm{PSC} / \mathrm{CAH}$ & $\mathrm{PBC}$ & 1AT-def & $?$ & $\mathrm{HBV}$ & $\mathrm{HBV} / \mathrm{HDV}$ & HBV \\
\hline Acute/chronic & $\mathrm{C}$ & A & $\mathrm{C}$ & $\mathrm{C}$ & $\mathrm{C}$ & $\mathrm{C}$ & A & $\mathrm{C}$ & $\mathrm{C}$ & $\mathrm{C}$ \\
\hline 1-year survival & + & - & + & + & - & + & - & + & + & - \\
\hline $\begin{array}{l}\text { Post-operative } \\
\text { days on ICU }\end{array}$ & 3 & 21 & 6 & 3 & 17 & 3 & 18 & 2 & 3 & 23 \\
\hline Duration SBD & & & & & & & & & & \\
\hline Preoperative & 4 & 1 & 3 & 6 & 10 & 31 & 2 & 14 & 8 & 35 \\
\hline Postoperative & 13 & 20 & 12 & 11 & 16 & 12 & 16 & 12 & 11 & 24 \\
\hline $\begin{array}{l}\text { SDD achieved } \\
\text { On day of treatment }\end{array}$ & + & - & + & - & + & + & - & + & + & + \\
\hline
\end{tabular}

* age at date of transplantation;

** $\mathrm{HBV}=$ hepatitis $\mathrm{B}$ virus; $\mathrm{HDV}=$ hepatitis $\mathrm{D}$ virus; $\mathrm{PSC}=$ primary sclerosing cholangitis; $\mathrm{PBC}=$ primary biliary cirrhosis; $\mathrm{CAH}=$ chronic active hepatitis; 1 ATdef $=\alpha 1$ antitrypsin deficiency; ? = diagnosis not possible.

One patient was retransplanted because of primary non-function of the graft. The surgical technique and first results of auxiliary partial liver transplantation in our clinic are described in detail elsewhere [15].

A number of data on patients and on the duration and the effect of SBD are listed in Table 1. In nine patients SBD was performed with the following orally adminstered regimen four times per day: colistin sulfate $200 \mathrm{mg}$, tobramycin $80 \mathrm{mg}$ and amphotericin B $500 \mathrm{mg}$, plus a mouth paste (Orabase ${ }^{R}$, Squibb, Regensburg, FRG) containing the same drugs in concentrations of $2 \%$. Because of lack of compliance to tobramycin, this drug was replaced by ciprofloxacin, $500 \mathrm{mg}$ twice daily in one patient (no. 10, Table 1). The parameter used for the achievement of SBD was elimination of gram-negative bacteria and fungi from the rectum and from the oropharynx. Patients with acute liver failure were started on SBD on admission to our hospital and patients with chronic liver disease when they were put on a waiting list for liver transplantation (Eurotransplant, Leiden, the Netherlands). SBD was discontinued after the last drain was removed. Twenty-four hours perioperatively, cefotaxime $(4 \times 1 \mathrm{~g})$ and metronidazole (4 x $500 \mathrm{mg}$ ) were given intravenously. All patients received anticytomegalovirus immunoglobulin $\left(\right.$ Cytotect $^{\mathrm{R}}$, Biotest Pharma GmbH, Frankfurt, FRG), $110 \mathrm{U} / \mathrm{kg}$ i. v., once before transplantation and then on days $3,7,14,30,60$ and 90 after transplantation. Both pre- and postoperatively, specimens were examined for bacterial, viral, fungal and protozoal pathogens. The efficacy of SBD was monitored by regular surveillance of specimens for bacterial and fungal pathogens. Bacterial cultures were performed semiquantitatively by using the four-quadrant method for aerobic and anaerobic pathogens [16]. The semi-quantitative cultures were estimated on a scale from one to four corresponding to the highest quadrant with bacterial growth. The preoperative bacteriological study consisted of two cultures per week from nose, throat, urine and faeces. These cultures were examined particularly for presence of gram-negative microorganisms and fungi. After transplantation, cultures were performed from blood, bile, wounddrain fluid, nose, throat, sputum, urine, faeces and stomach con- tents. For the first two weeks after transplantation this was done three times per week, subsequently once a week. Also, in case of signs of a bacterial or fungal infection, cultures from the infection site and blood cultures were performed.

Serum for virological study was obtained shortly before transplantation and in weeks 1, 2, 5,8 and 11 after transplantation, and subsequently at every outpatient check. Before transplantation, the serum of patients was examined for antibodies against hepatitis $\mathrm{A}, \mathrm{B}$ and delta, herpes simplex virus, varicella-zoster virus, cytomegalovirus und human immunodeficiency virus. After transplantation, detection of antibodies ( $\operatorname{IgM}$ and $\mathrm{IgG}$ ) to cytomegalovirus was done routinely. At the same times throat swabs and urine and blood samples were taken for rapid virus culture technique for demonstration of cytomegalovirus [17]. Antibody detection and cultures for the other viruses mentioned above were carried out only if indicated clinically. To monitor toxoplasma infections serum specimens were obtained from the recipients before surgery and at the times as mentioned for virus serology after transplantation. Serum from liver donors was acquired when available. Detection of antitoxoplasma IgG and $\operatorname{IgM}$ was undertaken with indirect ELISAs [18]. Portions of all sera were stored and run in parallel at a later date.

Definitions of infections: Infections were recorded according to the CDC definitions for nosocomial infections [19]. Primary cytomegalovirus infections were defined either by isolation of virus or by serocoversion in a patient who was seronegative before transplantation. Toxoplasma infections were defined either by a seroconversion or by a fourfold increase in antibody titer.

Immunosuppression: Immunosuppressive treatment was administered by means of intravenous infusion of prednisolone (25 $\mathrm{mg} /$ day), antilymphocyte globulin (ALG, Institut Mérieux, Lyon, France, 425 lymphocytotoxic units/kg/day) and azathioprine ( $1 \mathrm{mg} / \mathrm{kg} /$ day). Prednisolone was tapered off in 14 days to a maintenance dose of $10-15 \mathrm{mg} / \mathrm{kg}$ orally. Cyclosporin A was given i. v. on the sixth postoperative day at a dose of $3 \mathrm{mg} / \mathrm{kg} /$ day and subsequently at doses aiming at a serum level of $200 \mathrm{ng} / \mathrm{h}$ (polyclonal radioimmunoassay kit of Sandoz, Basel). After removal of 
Table 2: Bacterial infections and culture results during SBD $(\leq 20$ days after transplantation) and post-recolonization period ( $>20$ days after transplantation).

\begin{tabular}{|c|c|c|c|c|}
\hline Patien no & hedron & 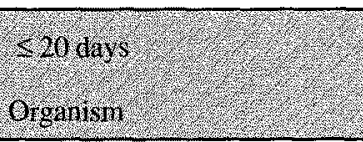 & 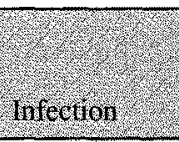 & $\begin{array}{l}\text { Organism } \\
\text { Oris }\end{array}$ \\
\hline 1 & None & & $\begin{array}{l}\text { Sepsis } \\
\text { Urinary tract }\end{array}$ & $\begin{array}{l}\text { Escherichia coli } \\
\text { Klebsiella/Escherichia coli }\end{array}$ \\
\hline 2 & Peritonitis & $\begin{array}{l}\text { Staphylococcus epidermidis / } \\
\text { Enterococcus }\end{array}$ & - & \\
\hline 3 & None & & Urinaty tract & Klebsiella \\
\hline 4 & None & & $\begin{array}{l}\text { Stomatitis } \\
\text { Cholangitis }\end{array}$ & $\begin{array}{l}\text { Candida albicans } \\
\mathrm{ND}^{*}\end{array}$ \\
\hline 5 & Peritonitis & $\begin{array}{l}\text { Staphylococcus epidermidis / } \\
\text { Enterococcus }\end{array}$ & - & \\
\hline 6 & None & & Peritonitis & Enterococcus \\
\hline 7 & None & & - & \\
\hline 8 & None & & $\begin{array}{l}\text { Wound } \\
\text { Stomatitis }\end{array}$ & $\begin{array}{l}\text { Staphylococcus aureus } \\
\text { Candida albicans }\end{array}$ \\
\hline 9 & None & & $\begin{array}{l}\text { Cholangitis } \\
\text { Liver abscess } \\
\text { Liver abscess } \\
\text { Wound } \\
\text { Cholangitis }\end{array}$ & $\begin{array}{l}\text { Escherichia coli } \\
\text { Candida albicans } \\
\text { Pseudomonas } \\
\text { Enterococcus/Pseudomonas } \\
\text { Enterococcus/Pseudomonas }\end{array}$ \\
\hline 10 & $\begin{array}{l}\text { Wound } \\
\text { Peritonitis }\end{array}$ & $\begin{array}{l}\text { Enterococcus } \\
\text { Candida albicans }\end{array}$ & - & \\
\hline
\end{tabular}

* ND = culture not done.

the biliary-drainage catheter in the bowel lumen on the tenth postoperative day oral administration of cyclosporin was started. This was adjusted to trough serum levels between 100 and 200 ng/. ALG and azathioprine were discontinued after the seventh postoperative day.

Transplant function: Transplant function was followed by means of determination of coagulation factors, liver enzymes, serum bilirubin and serum albumin. Also, on preset days Doppler ultrasonography, scintigrapy with technetium-99m-labeled diethylimidodiacetic acid and liver puncture were carried out.

\section{Results}

Four out of ten patients died in the early postoperative period (up to one month after transplantation [20]) with an inadequate or non-functioning graft. This applies to two patients with acute liver failure and two patients with chronic liver disease. In the other six patients, the graft function was good. SBD was started in the ten patients one to 35 days before transplantation (Table 1). In three patients, cultures showed that SBD had not been achieved on the day of transplantation. These were patients 2,4 and 7 who on the date of transplantation had received the SBD regimen for one, six and two days, respectively. SBD was achieved later in patients 4 and 7 , on the third and sixth day, respectively, after transplantation. In patient 2 , aerobic gram-negative bacteria were eliminated on the fourth postoperative day. Yeasts could be cultured from this patient's oropharynx throughout the SBD period. In three of the four patients who died, SBD was discontinued one to two days before death because of the bad prognosis.

For the determination of the nature and course of infections, in this study the postoperative period was divided into a period in which effects of SBD might affect the nature of the infections, and the period after recolonization of the digestive tract. In the six patients with an uncomplicated immediate postoperative course, the duration of SBD was 11 to 13 days, and the bacteriologic cultures showed that the duration of recolonization after termination of SBD was at most seven days. In view of these findings, the second of our two periods for determination of infections was reckoned to begin on day 21 after transplantation. The duration of follow-up varied from eight to 26 months (end date 31 December 1988).

Table 2 lists the findings concerning the nature and the causative organisms of the bacterial infections observed. No gram-negative infections were observed in the first 20 days after transplantation. Patient 10 developed a Candida peritonitis. This patient died in spite of parenteral treatment with amphotericin B. During the post-recolonization period (> 20 days after transplantation), serious infections of gram-negative origin occurred. In one patient (no. 1), $E$. coli bacteremia developed without a clear source. The urinary tract infection by $E$. coli in this patient was only observed 19 days after the sepsis. In another patient (no. 9) $E$. 
coli sepsis developed immediately after a routinely performed liver puncture three months after transplantation. Cholangitis must have been the source of this infection. The patient went into septic shock with severe renal failure necessitating a protracted stay in an ICU. During this stay, the patient was found to have developed a liver abscess due to Candida albicans. This abscess was drained and treated with amphotericin B intravenously. Subsequently, the abscess cavity became infected with Pseudomonas. Two months later, the patient once more developed cholangitis. From the bile, enterococci and again Pseudomonas were cultured. The cholangitis was found to be due to an obstruction of the choledochus that was corrected surgically. Thereafter the patient remained free of symptoms. Two patients (no. 1 and 3) developed a urinary tract infection with Klebsiella plus $E$. coli, and Klebsiella, respectively. In the postrecolonization phase the buccal mucosa in two patients (no. 4 and 8 ) showed a white coating. Cultures yielded $C$. albicans. Both patients were given antifungal treatment orally. It was observed that in five out of ten patients enterococci were cultured. During the first 20 days after transplantation, this microorganism was cultured from the bile drain in three cases (patients 3,5 and 10). Clinical sepsis was diagnosed in patients 2 and 5 . Both had peritonitis caused by enterococci and S. epidermidis. In one of these patients (no. 2), blood cultures positive for both organisms were obtained. In the other patient, the blood cultures remained negative. Both patients died of septic shock. During the post-recolonization phase, also, two patients developed enterococcal infections. One, a woman (no. 6) with an initially uncomplicated course, was readmitted 40 days after transplantation with high fever and abdominal pain. These symptoms proved to be due to peritonitis and sepsis caused by enterococci. In the other patient (no. 9), enterococci were cultured from an abdominal wound and from blood, and two months afterwards enterococci were cultured from bile. This time the patient had cholangitis due to an obstruction of the common bile duct.

Apart from a severe infection of the transplant with HBV, which occurred in all evaluable HBsAg-positive patients, problems due to viral infections remained limited in these ten patients. The data of the patients with regard to hepatitis $B$ are summarized in Table 3 . In the four evaluable patients (patient 10 died in the immediate post-operative period), the serological findings suggest a pronounced increase of the activity of hepatitis B infection. HBe-antigen appeared and anti-e antibodies disappeared, and the HBV-DNA in the serum either appeared or rose markedly. Pathological examination of liver biopsies (results not included here) confirmed the existence of an infection of the liver allografts in all four patients. Antibodies against hepatitis delta virus were present in two of the five $\mathrm{HBsAg-positive} \mathrm{pa-}$ tients.

As mentioned, all patients received passive immunization by means of anti-CMV immunoglobulin $\left(\right.$ Cytotect $\left.^{R}\right)$. One patient (no. 3) developed a primary CMV infection with high IgM-CMV titres and persistently positive virus cultures from urine, throat and blood in the period from two to 14 months after transplantation. There were no clinical symptoms during this infection.

Before transplantation, eight of the ten patients showed serological evidence of (latent) toxoplasma infection with antitoxoplasma IgG or IgM or both. Three recipients (one seronegative for Toxoplasma gondii infection, patient 4 received the graft from a donor seropositive for $T$. gondii. The serological status for toxoplasma infection was not known in six donors. Immediately after transplantation antitoxoplasma IgG, with an indirect ELISA IgG titer of up to $1: 80$, was found in sera of three recipients that was not detected anymore after seven weeks and apparently was passively acquired by blood transfusion. Two seropositive recipients showed a significant fourfold rise in anti-toxoplasma IgG titer followed by a conversion in IgM titer (from <1:20 to $1: 40$ ). The peak in IgG titers were reached five $(1: 1280)$ and 65 weeks $(1: 640)$ after surgery, in patient 3 and 1 , respectively. In the first patient this occurred after an episode of intensified immunosuppression and in the second case concomitantly with a reinfection of hepatitis B virus of the graft.

\section{Discussion}

In Rotterdam, 11 auxiliary partial liver transplantations were performed in ten patients between October 1986 and April 1988. All patients received selective bowel decontamination (SBD) to prevent infections by gram-negative microorganisms and fungi. According to throat and faecal

Table 3: Serological findings in hepatitis B positive patients undergoing auxiliary partial liver transplantation.

\begin{tabular}{|c|c|c|c|c|c|c|c|c|c|c|c|}
\hline $\begin{array}{l}\text { Patient } \\
\text { no. } \\
\end{array}$ & Before & Arer & $\begin{array}{l}\text { Anti } \\
\text { IIBs }\end{array}$ & $\begin{array}{l}\text { Anti } \\
\text { IIBC }\end{array}$ & $\begin{array}{l}\text { Betore } \\
\text { Bente }\end{array}$ & $\begin{array}{l}\text { se } \\
\text { Afrer } \\
\end{array}$ & $\begin{array}{l}\text { An } \\
\text { Before. }\end{array}$ & $\begin{array}{l}\mathrm{Be} \\
\mathrm{Aifer}\end{array}$ & $\begin{array}{l}\text { IIB } \\
\text { Before }\end{array}$ & $\begin{array}{l}\text { Niter } \\
\text { Ar }\end{array}$ & Anti \\
\hline 1 & + & + & - & + & - & + & + & - & - & $+*$ & - \\
\hline 3 & + & + & - & + & - & + & + & - & - & $t^{*}$ & + \\
\hline 8 & + & + & - & + & + & + & - & - & + & $t^{*}$ & - \\
\hline 9 & + & + & - & + & - & - & + & - & - & $t^{*}$ & + \\
\hline 10 & + & $\mathrm{NE}$ & - & + & - & NE & + & $\mathrm{NE}$ & - & $\mathrm{NE}$ & - \\
\hline
\end{tabular}

Results after transplantation are determined three months after date of operation.

$\mathrm{NE}=$ not evaluable (survival less than three months).

* increased up to maximal value of HBV-DNA $>26700 \mathrm{pg} / \mathrm{ml}$. 
cultures gram-negative organisms were eliminated in all patients before or shortly after transplantation. Only one patient failed to clear yeasts from his oropharynx.

No gram-negative infections developed in the first 20 postoperative days. Candida peritonitis was observed in one patient. After discontinuation of SBD, serious gram-negative infections and three fungal infections were seen. Accordingly, we conclude that in this group of patients SBD had a favourable effect in that it reduced infections by gram-negative microorganisms and fungi.

Most striking was the number of enterococcal infections that occurred in five out of ten patients. Examination of all surveillance cultures of patients who contracted an enterococcal infection showed in most cases an increase of enterococci in the faeces almost immediately after transplantation. A few days later, enterococci were then cultured from the wound area, bile drain or ascites fluid, and peritonitis and/or sepsis sometimes ensued. In at least two cases enterococci contributed to a fatal outcome. The frequent presence of enterococci cultured from specimens from liver transplant recipients an the development of enterococcal infections were mentioned only recently by Warren [21]. These patients all received systemic antibiotic prophylaxis for the prevention of gram-negative infections. The effect of SBD and of various other antibiotics on the composition of the faecal flora has often been described [22-26]. With SBD the aerobic gram-negative microorganisms can be eliminated from the bowel but enterococci remain at the same level or even rise in number. Although enterococci are regularly observed in the faeces of neutropenic patients protected by SBD, these bacteria rarely give rise to infectious manifestations in these patients. Our observations may point to the fact that liver transplant recipients who are protected by SBD remain at risk of acquiring infections

\section{References}

1. Krom, R. A. F.: Liver transplantation at the Mayo Clinic. Mayo Clin. Proc. 61 (1986) 278-282.

2. Busuttil, R.W.: Liver transplantation today. Ann. Intern. Med. 104 (1986) $377-389$.

3. O'Grady, J. G., Williams, R.: Present position of liver transplantation and its impact on hepatological practice. Gut 29 (1988) 566-570.

4. Maddrey, W. C., Van Thiel, D. H.: Liver transplantation: on overview. Hepatology 8 (1988) 948-959.

5. Starzl, T. E., Demetris, A. J., Van Thiel, D.: Liver transplantation (first of two parts). N. Engl. J. Med. 321 (1989) 1014-1022.

6. Starzl, T. E., Demetris, A. J., Van Thiel, D.: Liver transplantation (second of two parts). N. Engl. J. Med. 321 (1989) 1092-1099.

7. Ho, M., Wajszezuk, C. P., Hardy, A., Dummer, J. S., StarzI, T. E., Hakala, T. R., Bahnson, H. T.: Infections in kidney, heart, and liver transplant recipients on cyclosporine. Transpl. Proc. 15 (Suppl. 1) (1983) 2768-2772.

8. Colonna, J. O. II, Winston, D. J., Brill, J. E., Goldstein, L. I., Hoff, M. P., Hiatt, J. R., Quinones-Baldrich, W., Ramming, K. P., Busuttil, R. W.: Infectious complications in liver transplantation. Arch. Surg. 123 (1988) 360-364.

9. Kusne, S., Dummer, J. S., Singh, N., Iwatsuki, S., Makowka, L., Esquivel, C., Tzakis, A. G., Starzl, T. E., Ho, M.: Infections after liver transplantation. Medicine 67 (1988) 132-143.

10. Wajszczuk, C. P., Dummer, J. S., Ho, M., Van Thiel, D. H., Starzl, caused by gram-positive microorganisms, especially enterococci. It must be stressed that metronidazole and cefotaxime, used in this study as perioperative prophylaxis, do not disturb the intestinal anaerobic flora and thus do not interfere with the SBD [16].

The reconstruction of the biliary tract during the operation can be performed either by choledochocholedochostomy (end to end anastomosis of the donor's and recipient's common bile ducts) or by choledochojejunostomy (anastomosis of the common bile duct of the graft to the jejeunum) [5]. In our group choledochojejunostomy was performed in all patients. The possibility should be considered that this method constitutes a greater hazard with respect to infectious complications as mentioned by Kusne et al [9] .

In four evaluable patients with cirrhosis due to hepatitis B virus ( $\mathrm{HBV}$ ), infection of the graft with $\mathrm{HBV}$ occurred as suggested by serological and pathological findings. Reactivation of chronic hepatitis B may be seen in transplant patients given immunosuppression [27-29]. In liver transplant patients this infection is of special importance as a potential cause of graft failure $[13,14]$.

Cytomegalovirus and toxoplasmosis were reported to cause severe infections in liver transplant patients [30-33]. In our patients, however, no clinical problems from these organisms were seen.

In conclusion, there seems to be a favourable effect of SBD in that it may reduce infections of gram-negative or fungal origin. In our patients enterococcal infections took place in half of the patients. The use of SBD and the kind of biliary tract anastomosis probably play an important role. The findings in our patients with regard to the enterococcal infections give reason to react alertly with antimicrobial therapy on the appearance of enterococci in ascites or bile cultures in liver transplant recipients.

T. E., Iwatsuki, S., Shaw, B. Jr.: Fungal infections in liver transplant recipients. Transplantation 40 (1985) 347-353.

11. Cuervas-Mons, V., Martinez, A. J., Dekker, A., Starzl, T. E., Van Thiel, D. H.: Adult liver transplantation: an analysis of the early causes of death in 40 consecutive cases. Hepatology 6 (1986) 495-501.

12. Wiesner, R. H., Hermans, P., Rakela, J., Perkins, J., Washington, J., DiCecco, S., Krom, R. A. F.: Selective bowel decontamination to prevent gram-negative bacterial and fungal infection following orthotopic liver transplantation. Transpl. Proc. 19 (1987) 2420-2423.

13. Demetris, A. J., Jaffe, R., Sheahan, D. G., Burnham, J., Spero, J., Iwatsuki, S., Van Thiel, D. H., Starzl, T. E.: Recurrent hepatitis B in liver allograft recipients. Am. J. Pathol. 125 (1986) 161-172.

14. Ferla, G., Colledan, M., Doglia, M., Fassati, L. R., Gislon, M., Gridelli, B., Rossi, G., Galmarini, D.: B hepatitis and liver transplantation. Transplant Proc. 20 (Suppl, 1) (1988) 566-569.

15. Terpstra, O. T., Schalm, S. W., Weimar, W., Willemse, P. J. A., Baumgartner, D., Groenland, T. H. N., ten Cate, F. W. J., Porte, R. J., de Rave, S., Reuvers, C. B., Stibbe, J., Terpstra, J. L.: Auxiliary partial liver transplantation for end-stage chronic liver disease. $N$. Engl. J. Med. 319 (1988) 1507-1511.

16. van Saene, H. K. F., Stoutenbeek, C. P. Miranda, D. R., Zandstra, D. F.: A novel approach to infection control in the intensive care unit. Acta Anaesthesiol. Belg. 34 (1983) 193-208.

17. Rothbarth, P. H., Diepersloot, R. J. A., Metselaar, H. J., Nooyen, Y., Velzing, J., Weimar, W.: Rapid demonstration of cytomegalovirus in clinical specimens. Infection 15 (1987) 228-231. 
18. Sluiters, J. F., Balk, A. H. M. M., Essed, C. E., Mochtar, B., Weimar, W., Simoons, M. L., IJzerman, E. P. F.: Indirect enzymelinked immunosorbent assay for immunoglobulin $\mathrm{G}$ and four immunoassays for immunoglobulin $\mathrm{M}$ to Toxoplasma gandii in a series of heart transplant recipients. J. Clin. Microbiol. 27 (1989) 529-535.

19. Garner, J. S., Jarvis, W. R., Emori, T. G., Horan, T. C., Hughes, J. M.: CDC definitions for nosocomial infections, 1988. Am. J. Infect. Control 16 (1988) 128-140.

20. Rubin, R. H.: Infection in the liver transplant patient. In: Rubin, R. H., Young, L.S. (eds.): Clinical approach to infection in the compromised host. Second Edition. Plenum Medical Book Company, New York and London 1988, pp. 603-621.

21. Warren, R. E.: Difficult streptococci. J. Hosp. Inf. 11 (Suppl. A) (1988) 352-357.

22. van der Waaij, D., Berghuis-de Vries, J. M: Selective elimination of Enterobacteriaceae species from the digestive tract in mice and monkeys. J. Hyg. 72 (1974) 205-211.

23. de Vries-Hospers, H. G., Sleijfer, D. T., Mulder, N. H., van der Waaij, D., Nieweg, H. O., van Saene, H. K. F.: Bacteriological aspects of selective decontamination of the digestive tract as a method of infection prevention in granulocytopenic patients. Antimicrob. Agents Chemother. 19 (1981) 813-820.

24. van der Waaij, D.: Colonization resistance of the digestive tract: clinical consequences and implications. J. Antimicrob. Chem. 10 (1982) 263-270.

25. Chandrasekar, P. H., Smith, B. R., LeFrock, J. L., Carr, B.: Enterococcal superinfection and colonization with aztreonam therapy. Antimicrob. Agents Chemother. 26 (1984) 280-282.
26. Nord, C. E., Kager, L., Malmborg, A. S.: Effects of antimicrobial prophylaxis on colonization resistance. J. Hosp. Inf. 11 (Suppl. A) (1988) 259-264.

27. Nagington, J., Cossart, Y. E., Cohen, B. J.: Reactivation of hepatitis $B$ after transplantation operations. Lancet $i$ (1977) 558-560.

28. Parfrey, P.S., Forbes, R. D. C., Hutchinson, T. A., Kenick, S., Farge, D., Dauphinee, W. D., Seely, J. F., Guttmann, R. D.: The impact of renal transplantation on the course of hepatitis $B$ liver disease. Transplantation 39 (1985) 610-615.

29. Degos, F., Lugassy, C., Degott, C., Debure, A., Carnot, F., Thiers, V., Tiollais, P., Kreis, H., Brechot, C.: Hepatitis B virus and hepatitis B-related viral infection in renal transplant patients. Gastroenterology 94 (1988) 151-156.

30. Fox, A. S., Tolpin, M. D., Baker, A. L., Broelsch, C. E., Whittington, P. F., Jackson, T., Thistlethwaite, J. R., Stuart, F. P.: Seropositivity in liver transplant recipients as a predictor of cytomegalovirus disease. J. Infect. Dis. 157 (1988) 383-385.

31. Rakela, J., Wiesner, R. H., Taswell, H. F., Hermans, P. E., Smith, T. F., Perkins, J. D., Krom, R. A. F.: Incidence of cytomegalovirus infection and its relationship to donor-recipient serologic status in liver transplantation. Transplant Proc. 19 (1987) 2399-2402.

32. Ruskin, J., Remington, J. S.: Toxoplasmosis in the immunocompromised host. Ann. Intern. Med. 84 (1976) 193-199.

33. Kusne, S., Dummer, J. S., Ho, M., Whiteside, T., Rabin, B. S., Makowka, L., Esquivel, C. O., Starzl, T. E.: Self-limited toxoplasma parasitemia after liver transplantation. Transplantation 44 (1987) $457-459$. 